\title{
Radical empathy, the imaginary and affect in (post)colonial records: how to break out of international stalemates on displaced archives
}

\author{
James Lowry ${ }^{1}$ \\ Published online: 9 May 2019 \\ (c) The Author(s) 2019
}

\begin{abstract}
As the European powers appeared to withdraw from their colonies, they often took with them records that were subsequently claimed by the governments of the newly independent countries. These records are post-colonial examples of displaced archives. In recent history, the problem of displaced archives has been approached as a legal problem, and this has produced relatively few resolutions to archival claims. This article approaches displaced archives from a new perspective, applying theories and concepts recently introduced into archival theory by Michelle Caswell, Anne Gilliland and Marika Cifor: affect, imagined records and impossible archival imaginaries, and radical empathy. This article will show that these concepts, which have been deployed to decolonise diverse aspects of archival work, could also help resolve a persistent international problem, which is both technical and geopolitical/ diplomatic. This article will argue that archival theory, as recently influenced by Caswell, Gilliland and Cifor, demands a significantly changed approach to archival displacement, even as it sometimes arrives at established positions on repatriation and access. This change involves opening up dialogues about displaced archives to considerations beyond the juridical or geopolitical, to form richer understandings of archival displacement and its effects on individuals and communities. The article challenges individual archivists to apply the concepts of affect, imagined records and impossible archival imaginaries, and radical empathy in their work with colonial records as a component of decolonial archival praxis, and finally proposes a critical theorisation of displaced archives.
\end{abstract}

Keywords Displaced archives · Migrated Archive $\cdot$ Affect $\cdot$ Imaginary $\cdot$ Radical empathy

James Lowry

jlowry@liverpool.ac.uk

1 Liverpool University Centre for Archive Studies, Liverpool, UK 


\section{Introduction}

Since the modern period, international disputes over the ownership of archives have been approached from a rights-based perspective, a perspective that Caswell and Cifor (2016) have suggested has also characterised archival studies. My work has been firmly situated in this rights-based thinking, which I have found appropriate and useful in numerous practical projects, but which has not proved to be fruitful in settling international disputes over displaced archives. For example, in relation to the Migrated Archives - a high-profile case of displaced archives in Britain that I will describe below-many have argued that both orthodox archival theory and international law and (European) customary law calls for the return of these records to Britain's former colonies. Nevertheless, there have been no returns from this series. In what follows, I want to approach this problem from a different perspective, using concepts that have been developed in an archival context by Caswell, Gilliland and Cifor since approximately 2014. In the introduction to Displaced Archives, I asked what considerations of ideas recently introduced into archival studies might reveal about the persistent and often seemingly intractable problem of displaced archives (Lowry 2017). This article applies some of those ideas, which are, namely, affect, imagined records and impossible archival imaginaries, and radical empathy, to a case of archival displacement. These ideas are related insofar as they arise out of the milieu of the information studies programme at the University of California, Los Angeles, and are situated within a social justice paradigm (Cifor 2016, p. 8). Furthermore, they are related via a common heritage in critical feminist discourse and therefore interact and connect in multiple ways. As I will show, when applied to cases of archival displacement, they enable a richer understanding of the meaning and consequences of displacement, including in regard to current understandings of colonialism. I argue that, if they were used by those involved in disputes over displaced archives, they would help to correct the power biases in current multilateral work by making that work more inclusive and equitable. I will apply these ideas to the Migrated Archives as an example of displaced archives, and in particular I will consider the Kenyan records in that series. Before an explanation of what these records are, it is important to set out my position in relation to those records.

The subject and the methods of this piece require transparency about my own position in relation to the Migrated Archive. I am a white Australian resident in Britain and at least two generations of my family were involved in British imperialism's deployment of the working and lower-middle classes to populate the Empire and later Commonwealth with white or loyalist people: one in the Plantations of Ireland and another in the Assisted Passage Migration Scheme that coincided with the White Australia Policy. In my professional life, I have worked closely with archivists in many of the countries effected by the Migrated Archive, including Kenya, and I have witnessed but cannot speak for my colleagues' desire for the return of those records. I am currently the Chair of the Association of Commonwealth Archivists and Records Managers (ACARM), which was established in the 1980s as a forum for professional development and collaboration 
between record-keepers in the Commonwealth, though, judging from the documentation that survives, without a critical analysis of itself and its mission in relation to the legacy of colonialism. During my chairship, I have led the revision of the association's constitution so that it overtly states an aim to examine the repercussions of colonialism on record-keeping and through records, and, with Mandy Banton, I have prepared a position paper calling for the repatriation of the Migrated Archive, which was adopted unanimously by ACARM members at our 2017 annual general meeting. I currently do this work from the University of Liverpool, in a city once made wealthy by the exploitation of colonised lands and peoples, including through slavery. There is therefore a web of relations between myself and all of these systems, actors and events that is shaped by the colonialism that caused the Migrated Archives to be created, displaced, hidden, exposed and now under dispute. As a part of this web of relations, I have a responsibility to act ethically in hearing and supporting those with claims over the records and in addressing injustices associated with them. I will argue that all of the people enmeshed in this set of relations that proceeds from colonialism share this responsibility, particularly those people who currently have custody of the records.

\section{Displaced archives and the Migrated Archive}

Ketelaar (2017) has suggested that in a broad sense, all archives are displaced; they are all removed from the context of their creation. The term 'displaced archives', more specifically, refers to records not just removed but claimed by others. Numerous definitions of this phenomenon have been attempted (Kecskeméti 1977; Leisinger 1982; Mukula 1982; Nsibandze 1996; Garaba 2011; Mnjama 2011; Banton 2013). In my introduction to Displaced Archives, I used the term 'displaced archives' to refer to archives removed from the place of their creation and in particular 'those removals that are arguably not illicit 'thefts' but somehow legitimised or defensible by virtue of the fact of their being removed by states, regimes or exiled groups rather than individuals', foregrounding the element of dispute that is a feature of these cases (Lowry 2017, p. 4). In the same volume, Mnjama and I (2017) used a broader definition, drawing on the definitions of the archivists Nomsa Nsibandze and Francis Garaba, which centred the 'ethical implications of the movement of records while stopping short of demarcating the nature and context of the records and their removal' (Mnjama and Lowry 2017, p. 102). Other definitions are attempted in that book and elsewhere in the literature, but here, I am concerned with records removed from the place of their creation during decolonisation and where their ownership is disputed by the former colonies, now independent nations.

Archival displacement has been an issue for nation states, peoples, communities, archivists and other individuals for centuries. A full historical study of the phenomenon has yet to be written, but there are many high-profile cases, including the records removed to Russia during and following the Second World War: their location and conversations over their fate are expertly monitored and documented in the work of Patricia Kennedy Grimsted (see, for instance: Grimsted 2007). Another well known case is the Jewish archive removed to the USA from Iraq (Montgomery 
2017), which concerns minority communities, diasporas, private companies and nation states. The archival discourse around displaced archives has concentrated on disputes between nation states, but as I have previously suggested (Lowry 2017), there are many more configurations concerning First Nations, non-state actors, and others that have often been treated separately; these areas of work could be brought together to form a richer conception of the phenomenon.

Historically, displacements have been treated in a legalistic manner by the nation states that have disputed their ownership. That is, the international legal and archival communities have looked to international law for solutions, including customary European law, the laws of war, and the affordances of international détentes. This legalistic mindset is coterminous with the concept of the nation state as something juridically defined, and in relation to international negotiations, realised in accords that set out the rights of nations. This approach has produced relatively few resolutions to outstanding archival claims. Transfers between nations have usually come through bilateral negotiations on other issues, often economic and political imperatives such as trade or military cooperation. In these cases, archival transfers have been treated as gestures of friendship and goodwill, rather than the object of negotiations aimed at righting past wrongs or correcting illegalities, as Jos van Beurden observes in his study of cultural diplomacy (van Beurden 2017).

Recent examples of archival repatriations include returns from the Netherlands to Suriname and Indonesia, and returns from France to Korea (Cox 2017). An overview of outstanding cases is difficult given the diplomatically sensitive nature of the topic, which means that there is limited information in the public domain. Auer (1998) undertook an international survey of archival claims in 1997/8 on behalf of the International Council on Archives (ICA). He noted that the data were incomplete and that for 'whole regions we are left in the dark as to whether the lack of responses was due to political reasons, a lack of interest or a lack of disputed archival claims' (Auer 1998, p. 2). His survey found sixty-one extant archival claims arising from conflict, decolonisation or the succession of states. Currently, I am repeating the survey for the ICA's Expert Group on Shared Archival Heritage (EGSAH), but the aggregated data from the new survey are not yet available.

One case that came up repeatedly in the 1997/1998 survey, and which is expected to appear in the current survey, is the high-profile case of the Migrated Archive, which I will use as an example throughout the rest of this article. The records in the Migrated Archive were created or received by British colonial administrators-both British and locally engaged staff_-across the globe. They were removed to Britain at the 'end of Empire'. The earliest documentation of pan-African conversations about records removed to Britain refers to them as 'migrated archives' (ECARBICA 1969), and that term has been widely used by archivists in Commonwealth countries, but the term has gained currency as a proper noun since the 'discovery' of a collection of colonial records at the Foreign and Commonwealth Office (FCO). The Migrated Archive is now a series (FCO141) at the (UK) National Archives (TNA) at Kew in west London, but it was formed from a collection of papers discovered at FCO premises at Hanslope Park, north of London, following the discovery phase of the 'Mau Mau' lawsuit (Banton 2013). In this suit, four Kenyans made a claim against the British government for compensation for abuses that occurred during the 
British clampdown on the independence movement (the so called Mau Mau Emergency) during the 1950s and 1960s. The claimants were successful, but the archival aspect remains unresolved. The Kenyan government and some other independent governments of the former British colonies have expressed a desire to have the displaced archives repatriated or copied (Mnjama 2007, 2015).

The British government has not returned the records to the countries in which they were created, claiming that they are British public records, following legal advice in 2011 that has not been made public. As Mandy Banton has shown, the British position on the ownership of these records has been inconsistent, and hinges on interpretations of 'public record' in the Public Records Act 1958 and the nuances of the structures of colonial governance arrangements (Banton 2013, 2017). Currently, the majority of the records are available for consultation at TNA; those that are not are retained by the FCO. The records at TNA may be read by anyone who can visit Kew. They have not been digitised. Following approaches by the Association of Commonwealth Archivists and Records Managers (ACARM), TNA indicated that it could not prioritise the digitisation of the series as part of its ongoing digitisation programme, but that items in the series, like most records at TNA, could be 'digitised on demand' on request and payment of a fee. In response to the suggestion that ACARM might crowdfund the digitisation of the records, TNA provided ACARM with a cost estimate of over 6 million pounds, and preliminary discussions seemed to suggest that copyright would have to remain with TNA, with recipient national archives only allowed to provide access to the digital surrogates on site in their reading rooms. Crowdfunded digitisation was determined by ACARM to be infeasible because of the high costs and unsatisfactory intellectual property requirements.

Currently, two options are open to the Kenyan government if it wishes to pursue repatriation. Firstly, it could pursue a legal case for the return of the records. A successful claim would open the door to the return of other parts of the Migrated Archive to the countries in which they were created. Secondly, the Kenyan government could make a diplomatic approach through the Ministry of Foreign Affairs. If full repatriation is the goal, these two options are the only options available to the Kenyan government if the problem is approached in a rights-based, legalistic or orthodox archival way. As I will show, new ways of looking at this problem are made possible by recent developments in archival theory.

\section{Affect}

Cifor states that 'definitions of affect understand it as a force that creates a relationship (conscious or otherwise) between a body (individual or collective) and the world. Some definitional ambiguity creates generative space, however, for rethinking the interrelations between the psychic, the body and the social' (Cifor 2016, p. 10). Gilliland and Cifor point out that a concern with affective responses to records and the processes of record-making and record-keeping started to emerge in the archival literature from around 2008. The November 2014 Affect and the Archive symposium at UCLA was a critical point in this opening up of archival theory to the affective and, with the 2016 special issue of Archival Science that resulted, could be said to 
mark an affective turn in archival studies (Cifor and Gilliland 2016). Since 2016, there has been a marked shift in the archival discourse, seen in journal articles, conference papers, blogs and social media conversations, where the personal, embodied and emotional is given space and serious treatment, in contrast to the established dominance of the official or institutional, the neutral and tangible [i.e. see Brennan (2018), Russell (2018) and TNA's (n.d.) research priorities, which claim an interest in 'physical and sensory responses to collections': 'We will also explore the role of the archivist: how they represent and react to affect, and how the records affect archivists themselves' \& TNA n.d.)]. Of particular importance in this turn was Cifor's article 'Affecting relations: Introducing affect theory to archival discourse', which provided an overview of the concepts and history of affect theory, with some thoughts about how the theory might be deployed in archival theory, practice and professionalism (Cifor 2016). Among other arguments and observations, Cifor argued that affective value should be a consideration in appraisal, that archivists, as witnesses to the affective power in records, have a responsibility to give effect to that power by using records in society, and that archivists should analyse their affective attachments to dominant and damaging professional paradigms. I will consider each of Cifor's core arguments in relation to the Migrated Archives.

In a letter received by the District Commissioner of Kabarnet, in Kenya, on 20 November 1958, Mbiyu Koinange, later a Minister in Jomo Kenyatta's government, wrote:

Sir,

I have the honour to submit this application requesting you whether you will allow me to come there and see my father.

I would like to ask you whether you can let me come there with my wife. I have stayed for many years without seeing my father since he went away. I was very small boy and now I am a full grown up person and I have married and my wife want to see my father, therefore I ask you kindly to admit me.

I have asked the Chief about that and he agreed he said he has no any objections. I did not take any Mau mau oaths neither my wife and we have gone under Screening Team and we were issued certificates.

My aim of coming there is just to see my father and to introduce my wife to my father because she has never seen him before.

I hope to get your favourable reply under your sympathttitically consideration.

I beg to remain,

Sir,

Yours faithfully,

MBIYU KOINANGE (Koinange 1958)

Koinange's father, the Kikuyu chief Koinange wa Mbiyu, was in detention for his support of the Mau Mau movement. The content of the letter has an affective 
power-the humble plea of a young man to see his ageing father shows vividly the power of the colonial administration over the lives and movements of real people. Cifor talks of affect in relation to the production, reception and use of archives. This letter is typed and Koinange's return address is care of the Banana Hills post office, 'via Limuru'. How was this record made? Did he use his own typewriter, or did he dictate the letter? What people and systems were involved in carrying it from Banana Hills to Kabarnet via Limuru? Then, how was the letter kept? There is no indication of whether or not Koinange was granted permission to visit his father, but in the memos and reports that flank this letter, bureaucrats discuss his father's ill health and possible arrangements for the burial of his body away from his ancestral home, to preclude his memorialisation as a local hero of the Mau Mau cause. They use cool and sometimes wry tones, in contrast to Koinange's heartfelt request. From a rights-based perspective, this letter is simply a request that it should have been possible to answer according to a set of predefined rules. From an affect-oriented perspective, this letter helps to illuminate a person, a family and community, a set of power relations and a regime of control with personal and emotional consequences, as well as physical and juridical consequences.

In regard to appraisal, we know that this series was formed by the application of guidance that was heavily biased towards the departing colonisers, ambiguous in its terms, and applied unevenly across the colonies. This guidance stated that records to be withheld from incoming governments were those records that:

(a) Might embarrass H.M.G. [Her Majesty's Government] or other Governments;

(b) Might embarrass members of the police, military forces, public servants or others (such as police agents or informers);

(c) Might compromise sources of intelligence;

(d) Might be used unethically by Ministers in the successor Government. (Colonial Office 1960-62)

In view of the stories of records burned in bonfires and sunk in lakes as the colonisers withdrew, the Migrated Archives can be seen as 'a sliver of a sliver' of the records of the colonial period (Harris 2002). The criteria concern 'embarrassment' and inappropriate use in ways that demanded the colonial officers to make judgements that will inevitably have been shaped by responses to contexts around and particular data points within the records. Stoler (2010) notes a characteristic of colonial bureaucratic culture - the place of personal discretion in decision-making and its distillation into forms of words that were read not only as reports of occurrences but as representations of the abilities of the officer making the report. That is, the language, tone, inclusions and omissions were used to judge the bureaucrat's suitability for responsibility and promotion, transfer or demotion. In a similar way, the British criteria seem to expect an implicit understanding of what would constitute a sensible and appropriate application of the guidance to the appraisal of records. Between the written guidelines and their implementation, there will have been much subtle, contextual sense-making, but this will have been driven by the 
political imperative to defend a regime in retreat. There will have been no parallel drive to preserve records that had affective power to communicate the perspectives of records subjects or more fully illuminate colonial rule.

Those records that survived this appraisal were removed to Britain and may have been exposed to any number of subsequent appraisals while in FCO custody; again these appraisals will have had no regard for representativeness, nor for affective power. The Migrated Archive, then, was shaped without a concern for the affective ability of records to tell the stories of the under-represented and oppressed. Following the Mau Mau litigation, the records were transferred to TNA, though some parts are retained or closed. Koinange's letter survived appraisal because it relates to the custody of a prominent person of concern to the security forces of the colonial state. An affective lens during appraisal may have seen material survive that might have helped us form a much clearer picture of the effects of the colonial state in Kenya on individuals, families and communities.

Affect, then, will not have been an appraisal criterion in the formation of the Migrated Archive, but it can be used now to think about this series. I may feel sympathy for Koinange and anger that he should have to ask permission to see his father, who was imprisoned for 8 years and released at the age of 95, 19 days before his death, (Mwaura 2012) but the responses of the people of Banana Hills, Limuru or Kabarnet, who may have known Koinange, his wife or father, might see much more in this letter, may have lived through its contexts and participated in the events from which it emerged. The people of those places may never see this record, and in any case will not see it so easily as I have. A reappraisal using affect might suggest that these records have more power in the places of their creation than in Britain and that the Migrated Archive is more appropriately broken back down into the component parts from which it was made, and those component parts returned to the places of their creation.

In her second argument, Cifor makes the case that 'As witnesses, archivists should become instruments of societal justice aiding larger society in ethical and meaningful witnessing processes' (Cifor 2016, p. 18). There is an ongoing need for witnessing British imperialism by British people, in terms of its historical instantiations and its repercussions. The brutality of the abuses experienced by the Mau Mau litigants demonstrates the reality of the British presence in its former colonies and reminds us that its victims are either relegated to memory through murder, neglect or the passage of time, and that its survivors may be living with its scars. Its less embodied effects are deeply political; a 2014 survey found that 59\% of British people thought that the British empire was something to be proud of (Dahlgreen 2014), and there is a discernible nostalgia for the period in British film and television, which arguably coincides with the rise of nationalism exemplified in the Brexit referendum result. Developing the idea of the archivist-as-witness, Cifor writes that

... we should let it hurt to hear words such as those contained in the testimonies. Following Ahmed, we have an ethical obligation to witness, while to ignore or to forget would be a repetition of the violence and injury of the subjugated, marginalized peoples who have not yet had their pain (and other affects) recognized... (Cifor 2016, p. 21) 
Archivists can witness the Migrated Archives at at least two levels. At the most intimate level, there is the witnessing of the lives and affects intimated in the letters, reports and indexes that constitute these files, such as Koinange's letter. This might prompt archivists to ask themselves, 'who am I in relation to these lives and affects?' Sitting at TNA on a grey September day, if I step into the role of archivist while I look at these papers, I feel that I am an interlocutor: these lives and affects concern another place, far away from this reading room. In that far away place, the colonial bureaucrat who created or received these records was also an interlocutor, and taking charge of these records that do not concern my communities, or the places I belong to, arranging and describing them, I become an interlocutor in those same places. This reflection brings into view, for me, the parallel between the violence of the colonial state and the bureaucratic violence of British custodianship of these records. These records only exist because of the imperial project, because the British were in Fiji or Sierra Leone or Palestine, but these records are things that were done to other people and places. By letting the affective into my reading of these records, I can bear witness to individual lives and affects that bring me to bear witness to the larger series in the context of its history and custodianship. And finally, how much more richly and powerfully will be the affective responses of the archivists and users of the former colonies? As Lee (2016, p. 45) writes, 'As captive, the archival body is marked in time and space; the body is held together and made legible_-regulatedthrough temporalities such as rhythm, pace, cadence and duration. As archivist and researcher, I interpret the records and make meaning of them through my own lived contexts of space and time'. I have previously (Lowry 2017) used the analogy of the body to describe the dismemberment of the archives of the former colonies: what this dismemberment means, presently, is that my meaning-making through my contexts of space and time are given precedence over and take the place of the meaningmaking of the peoples these records are about. This body is captive here, with me. Cifor writes that 'Ahmed calls on us as archivists, scholars and persons implicated in complex power relations to witness and to do the difficult work of negotiating collective narratives of pain, past and present, in the archives and far beyond it' (Cifor 2016, p. 22) but in this case, which archivists should be doing that work?

In her third core argument, Cifor considers how affect interacts with neoliberalism in archives. She writes that it is in addressing attachments to and investments in unjust social norms that affect theory can intervene in the developing scholarly and professional discourse on neoliberalism' (Cifor 2016, p. 24) and uses Berlant's concept of 'cruel optimism', the attachment of people to systems that disadvantage them in the hope of attaining the 'good life'. As Cifor and Lee later elaborated, this cruel optimism ties subjects to 'structures that serve to subordinate people' (Cifor and Lee 2017, p. 6). A good life in archives, Cifor writes, includes abundant resources and opportunities, equitable access for all, archival job security and fair compensation and societal recognition of the value of archives. It is cruel optimism that engages those in the archival field in an unending search for these measures of security and prosperity against the spectre of their impossibility within present systems' (Cifor 2016, p. 25). Cifor's argument uses the privatisation of digitisation as an example of cruel optimism, where the aspiration to enhanced access entices archival institutions into contracts with private companies that can be problematic 
in other ways, for example with regard to intellectual property rights. As discussed above, ACARM's approach to TNA over the digitisation of the Migrated Archives, embedded in a rights-based framework and entangled in financial considerations, property rights, and local service delivery priorities, reached a dead end. To cling to the view that a solution is available under current conditions is to persist in cruel optimism. No resolution through digitisation is likely in practice, though it remains possible in theory.

In summary, allowing affect into engagements with the Migrated Archives challenges British possession of these records. In relation to appraisal, affect, though applied here post hoc, raises the question of the joining together of these disparate series as FCO141 and the appropriateness of their retention in Britain. With respect to the notion of witnessing affect, two points arise. The first is that the ongoing custodianship of these records at TNA parallels the violence of colonialism, and the second is that while held in Britain, the records are not being used fully by TNA's archivists to bear witness to British imperialism. Finally, an affect-centred perspective on these records recognises current conditions for their digitisation as embedded in and limited by a broader socio-economic state of neoliberal cruel optimism.

\section{Imagined records and impossible archival imaginaries}

Gilliland and Caswell (2015) published an article that considered records that individuals, communities or societies might imagine exist or existed. They developed this idea in their contribution to the (2016) special issue of Archival Science in relation to the affective responses to imagined records, and the concept of 'impossible archival imaginaries'. Caswell had previously defined archival imaginaries as

... the dynamic way in which communities creatively and collectively re-envision the future through archival interventions in representations of the shared past. Through the archival imaginary, the past becomes a lens to the future; the future is rooted in that which preceded it. Through the archival imaginary, the future can be conceived through kernels of what was possible in the past (Caswell 2014).

Gilliland and Caswell use the impossible archival imaginary to explain 'how archival imaginaries may work in situations where the archive and its hoped-for contents are absent or forever unattainable' (Gilliland and Caswell 2016).

The records destroyed at the 'end of Empire' now only exist in the imaginary. As the bonfires destroyed the tangible records, they created an impossible archival imaginary; a space in which any number of records may have existed, and may have documented missing family members, named informants and collaborators, or identified those who ordered torture in the detention camps. The records that were left to the incoming administrators of independent Kenya were known by them to be partial because of the destructions and removals. At the moment of Kenyan independence, both the destroyed records and the removed records entered the imaginary, and as imagined records became a myriad of possibilities, secrets, stories and truths. 
Caswell and Gilliland observe that in 'some cases, actual and imagined records confront each other with alternate realities, one representing "the establishment', and the other, disaffection with or opposition to the establishment. In others, they interact in ways that co-constitute new realities or open up new possible futures' (Caswell and Gilliland 2016, p. 71). Following Caswell and Gilliland's idea that cultural productions can be considered instantiated imagined records, Ngũgĩ wa Thiong'o's (1967) novel A Grain of Wheat could be read in this way. The book provides a depiction of life in the Kenyan detention camps that agrees with the records in the Migrated Archives, despite their silences. The book was published in the same year that the Kenyan government made its first request for the return of the records and, as such, Thiong'o's story is an imagined record (though no doubt drawing on accounts of the camps) created in the absence of many actual, instantiated records. After 2011, it became possible to compare A Grain of Wheat with the records created by the colonial state and removed to Britain. In both sources, there are correlations in the bureaucratic euphemisms, the descriptions of abuses, and the behaviours of freedom fighters, collaborators and white colonialists. A similar dynamic is observed by Cobain (2016, p. 106), who points out that Caroline Elkins' 2005 book Imperial Reckoning, which first described Britain's abuses in Kenya, drew criticism for depending on the oral testimonies of Kenyans who remembered the detention camps. Those testimonies would be corroborated by official records when the Migrated Archive came to light. Though oral testimonies are not 'imagined records', they share a subaltern status in many legal and academic value regimes. Instantiated imagined records, then, challenge official narratives and fill silences in official archives. They help us read official records more critically by reminding us that other stories exist.

The Migrated Archives existed simultaneously as imagined records and actually existing records, and they persist in this state due to the ongoing closure of numerous extracts, together with the suspicion that more records from that or different series might exist in some forgotten corner-a suspicion only supported by the circumstances of the 'discovery' of the Migrated Archives. This paradoxical state as extant and imagined records means that for many the records may still offer the hope of some knowledge of a parent or grandparent, a corroboration of a family history, or deeper understandings of their lands, politics or histories. On the eventual release of the records, their contents may have disappointed many, being filtered through a series of heavily biased appraisals. However, importantly, for most Kenyans who are aware of them, they still exist in the imaginary, situated in the stacks of a distant archive and unavailable online.

Applying the concepts of imagined records and impossible archival imaginaries to the Migrated Archive shows how acts of archival displacement produce archival imaginaries that may always be impossible. While the repatriation of the Migrated Archives would move instantiated records into the realm of the real for the Kenyan archivists and users who can only imagine them while they remain at TNA - while repatriation would close down, in a sense, that imaginary space - the act of displacement also opened other imaginaries that cannot be closed down. We see, in archival displacement, archival imaginaries made impossible because they are unresolvable: more records may always be believed 
to exist. Following the first removal, any number of never-existing records may be imagined destroyed or secreted somewhere. Repatriation, then, may only ever partially restore the imagined displaced archive. Something intangible is lost in the physical act of displacement, and repatriation can therefore only ever be a partial restoration.

\section{A feminist ethics of care and radical empathy}

Caswell and Cifor (2016) argued for a shift from a rights-based approach to archival work to one based on a feminist ethics of care, building on earlier work by Caswell on a survivor-centred approach to records that document human rights abuses (Caswell and Cifor 2016). A feminist ethics of care would, among other things, value empathy. According to Caswell and Cifor, 'an archival approach marked by radical empathy would require archives to make survivors and implicated communities not just a target group of users, but central focal points in all aspects of the archival endeavour, from appraisal to description to provision of access' (Caswell and Cifor 2016, p. 24). Caswell and Cifor propose four interrelated shifts in relationships between archivists and records creators, subjects, users and communities, each characterised by a mutual affective responsibility. This shift is proposed in the light of work that found 'that dominant rhetorics of autonomy, individual freedoms and rights, choice, and neutrality were meaningless to many women, who are socialized into a caregiving role and whose moral decision-making is deeply relational, context dependent, and emotionally resonant' (Caswell and Cifor 2016, p. 28). This same dominant rhetoric imbues the discourse around displaced archives, as it does orthodox archival theory in general, with a sense of objectivity that, in the case of displacement, suggests that all claims can be reconciled by establishing the legal rights of nations and the true facts of the history of their interactions. What would a shift to a feminist ethics of care look like in cases of archival displacement? Taking the Migrated Archives case as an example, how would radical empathy change the relationship between the archivists at Kew and the records creators, subjects, users and communities?

\section{Caswell and Cifor state that}

The notion of empathy we are positing assumes that subjects are embodied, that we are inextricably bound to each other through relationships, that we live in complex relations to each other infused with power differences and inequities, and that we care about each other's well-being (Caswell and Cifor 2016, p. 31).

Already, this causes me to rethink TNA as a group of people personally charged with taking care of the records, rather than as monolithic and singular entity. From this changed perspective, thinking about the custodianship of the records happens at the individual, rather than the organisational level, and each archivist is implicated in the question Caswell and Cifor have set out: How are we archivists empathising with the creators, subjects, users and communities of these 
records? This question arguably prompts a move towards centring people and communities that would arrive at a recognition of the needs of Kenyan people and communities. A shift to this way of archival thinking at the level of praxis could trickle up to effect policy, particularly if TNA staff were to become activist.

Noting the limits of empathy, Caswell and Cifor warn us 'not to reinforce hierarchies that permanently position some as caregivers and others as care recipients' (Caswell and Cifor 2016, p. 32). This note of caution is particularly pertinent in the post-colonial context, where international relations have involved development aid funding that has been conditional on the adoption of laws, systems and practices by recipient countries and has been used as a tool of foreign policy and diplomacy. In many archives where empathy might be mobilised, there may be an expectation of ongoing service provision, but in the case of the Migrated Archive, caregiving from TNA to Kenyan users could constitute a reinforcement of a caregiving hierarchy. This could be avoided if that caregiving passed to Kenyan archivists, rather than being provided on an ongoing basis by British archivists.

In counterpoint to established archival practice in the west, which privileges the rights of the records creators, in 'the feminist approach, the archivist cares about and for and with subjects; she empathizes with them' and from this perspective considers records subjects in making decisions about the archives (Caswell and Cifor 2016, p. 36). The authors point out that this view aligns with work on co-creatorship and Indigenous claims to records; it also aligns with the concept of 'rights in records' articulated by Gilliland in 2014 and explored by Gilliland and McKemmish in 2016, though that work is framed in a rights-based way. Caswell and Cifor's proposed approach would see the archivist attempt to understand the possible desires of records' subjects. This might concern who is allowed to access or manage records about certain subjects, people or places. There may be local cultural knowledges or practices that should inform decisions about access and management. So far removed from the Kenyan cultural context are the staff of TNA, that these considerations would be difficult to make, and the question becomes 'which archivists could best serve the subjects of these records'?

In the third relationship of responsibility, archivists are called on to consider users. TNA archivists may demonstrate affective responsibility to users of FCO141, but in cases where records are claimed by more than one party, a radical empathy requires the expansion of the concept of users to include those potential users who are being excluded from using the records by current custodial arrangements. The Migrated Archives are situated outside of the reach of most Kenyan users, and no steps have been taken to provide digital access for them as prospective users. Radical empathy, in this case, would rebalance the asymmetry between British and Kenyan users and, at the least, open dialogues about repatriation or digitisation.

The fourth affective responsibility is to the community. In almost any application of this term-village community, Luo community, Kikuyu community, Kenyan community, Commonwealth community, international community, etc.- the affective responsibility of the archivist is contextually appropriate archival practice which, as has been established, is problematic if not impossible from Kew. Access is the most clear example. The community that is currently served best in terms 
of access to these records is the community of British researchers and those with money to travel to Kew. And beyond access, what service is being rendered by TNA to the British community? The potential of these records to educate the public about British imperialism, at this moment when colonial nostalgia is discernible not only in the xenophobic rhetoric of the right but in mainstream popular culture, remains untapped by TNA.

Caswell and Cifor note the complexity of navigating these sometimes competing or contradictory responsibilities, but in the case of the Migrated Archive, radical empathy would require a total shift — a relinquishing of ownership so that culturally appropriate custodianship might be effected on Kenyan soil, by Kenyan archivists, who would be better placed to understand the needs of the creators, subjects, users and communities of these records. TNA archivists who embrace radical empathy as an archival methodology would find in it an impetus to push for the repatriation of these records. And in the interim, there are considerations of access and outreach that better serve all of the communities around these records.

\section{Critical theory and displaced archives}

These concepts help in rethinking the Migrated Archives, but in them there is a basis for a new, critical approach to archival displacement more generally. Caswell, Punzalan and Sangwand have defined critical archival studies as 'those approaches that (1) explain what is unjust with the current state of archival research and practice, (2) posit practical goals for how such research and practice can and should change, and/ or (3) provide the norms for such critique' (Caswell et al. 2017, p. 2). Critical archival studies of displaced archives are necessary for richer and more deeply contextualised understandings of displacement. There is an impetus for a new theoretical approach of this kind in the failure of the juridical perspective to advance solutions that provide historical justice and equity today. Following Caswell, Punzalan and Sangwand's definition, a critical theory for displaced archives would be critical in its aim to explain injustices in cases of archival displacement, posit practical goals for their resolution, and provide a set of norms for achieving those aims-preliminarily affect, the imaginary and radical empathy. Such a theoretical move would recognise the need to make multilateral work on archival displacement, and ultimately the custody and access to records, more equitable. It would vary from the juridical view of displacement in that it would recognise that the structures that underpin that view - the laws, the international relations, etc. - are problematic legacies of historical power imbalances and abuses. Furthermore, it would vary from orthodox archival theory by recognising that records are more than property with provenance, and more than their values as legal and historical evidence, archivists are more than custodians, and records subjects and users are more than rights holders or data points. In a critical displaced archives theory, archives are affective, archivists empathise with and are empowered to support all those connected to the archives, and subjects and users are recognised to have complex needs for records beyond research or legal protection. 
This proposal for a critical displaced archives theory comes from a position of privilege outlined above, but to be truly critical, such a theory must be co-created. Listening to those with claims over records should go beyond bilateral and multilateral discussions and into building a theoretical treatment of displaced archives that is developed from or with local, Indigenous, and non-Western perspectives. The theorising itself could be modelled on the notions of care and radical empathy described above, fostering inclusivity, and it should heed Caswell and Cifor's warning about establishing and reinforcing care dependencies. It should encourage selfawareness amongst all parties that they are engaged in relations of power that should be navigated ethically and critically. Furthermore, these concepts have been developed in the global North, and must not become another colonising force. So this is a proposal only: A critical displaced archives theory in which feeling informs custody, repatriation is recognised as only ever partial (perhaps recognising that something other than context is lost in the severance of the archival bond), and empathy permits a nuanced understanding of the overlapping stakes in displaced records. A critical theory of displaced archives would recognise the international socio-economic environment as a significant factor in displacement, and in particular that conversations over repatriation and digitisation are often occurring in a state of cruel optimism. An equitable conversation requires an acknowledgement of the power asymmetries that go beyond, though often mirror, the possession of the records. In outstanding claims, the political power required for repatriation and digitisation initiatives is both consequent and causative: power derives from possession and possession reinforces power. But this dynamic does not occur in isolation. Cases persist within and arguably because of the socio-economic structure of global relations. In the postcolonial context, displacements parallel political and economic power imbalances built on the back of colonial exploitation. Neoliberalism's cruel optimism masks this. It decontextualises the displaced archives issue from these broader power relations, inviting us to believe in possibilities such as crowdfunding digitisation with fair sovereignty over the digital surrogates, without recognising that the biases in the intellectual property rights regime, technical processes and cost-setting apparatuses are connected to each other and embedded in inequitable global socio-economic systems that evolved from the colonial period.

Elaborating and applying a critical theoretical lens, conversations would not be confined to nation states, but permit many voices to speak through and around the records: subjects, users, archivists and others would be acknowledged as participants in dialogues about the custody, access and uses of records. Although there is some overlap in outcomes between the rights-based and this newer perspective-for instance, how an affective reading of the Migrated Archive supports the imperative for repatriation that is also recognised in rights-based archival thinking-applying the theory to disputed claims might in other contexts produce outcomes quite at odds with rights-based approaches. For example, thinking juridically about the Algerian records in France might focus on colonial Algeria's representation in the French parliament and conclude that those records are properly French national property. Critical displaced archives theory might challenge that conclusion by looking beyond legal structures to consider relations of care. Applications of the theory would also show that the act of displacement has permanent consequences that may 
not otherwise be recognised by governments and other actors-the archival imaginaries that are opened up may be impossible to close and might become, instead, part of the historical and cultural understanding of the relations between actors.

A critical theory for displaced archives stands to be developed. It may have its limits, but those are still to be identified through application to the many cases of archival displacement that persist internationally.

\section{Conclusion}

Taken together, the concepts of affect, imagined records and impossible archival imaginaries and radical empathy offer an alternative to the legal and diplomatic approaches that have so rarely resolved cases of archival displacement. With regard to the Migrated Archive, these concepts support the legal theory and traditional archival theory that demands the return of these records, but these concepts offer new tactics for reaching that goal. They all act at the level of the individual archivists in charge of the records. Those archivists are challenged to consider their own affective responses to these documents, to ask if the records are among those imagined by people in the former colonies, and to embrace a radical empathy with those people.

Koinange's letter can be read in two ways, though they are not mutually exclusive: as a request to visit an inmate, which can be acted upon, and as an expression of a desire to see an ageing father last seen in youth, which can be felt. I have suggested that many more affects may be felt, and more powerfully, by those connected to the people and places in that letter. There was much room for interpretation and variation in the first appraisal of the records in FCO141. Appraisal practices that recognise this and foster a more sophisticated working through of appraisal decisions-ones that admit affect and its social justice imperative-engender richer archives, but they also raise connected questions about the appropriateness of custodianship or access arrangements. An archival practice that makes space for understanding and valuing affect would create much different archives, and applied post hoc to an appraisal of the Migrated Archive, affect suggests a deaccessioning of the records from TNA. To do otherwise would be to replicate the colonial dynamic in the archive. To stop short of repatriation in the hope that a digital alternative will be found satisfactory and affordable is to be caught in a cruel optimism. Furthermore, affective archival work, as Cifor has argued, calls on archivists to witness, and I have suggested that the archivists at TNA are not presently bearing witness to the difficult affects of the Migrated Archive. This could be done by using the records, while they remain in British custody, to illuminate British colonialism.

Many records of the colonial period exist in an impossible archival imaginary, burnt or submerged and thereby opening up a space for imagining any number of facts and stories that will never be exposed. The Migrated Archive, thoughknown to exist but unknown in its size and scope-was an archival imaginary. It was not impossible, but attainable. Those imagined records, once transferred to TNA and opened, may have disappointed people hoping for answers to their 
questions, or different or better information, but they did not contradict understandings of the violence of British colonialism such as is set out in Thiong'o's A Grain of Wheat. In this case, the real records corroborated, to some extent, the imagined record. Simultaneously and paradoxically, on the revelation of the Migrated Archive, it turned from an archival imaginary into an impossible archival imaginary. Its 'discovery' some 50 years after its return was first requested only prompts suspicion that more records lie hidden in British government offices, and in this sense the edges of the Migrated Archive imaginary continually unfurl. Those records that are at TNA, though, may still exist in an imaginary state for the potential users who cannot access them. Thinking about FCO141 in terms of the imaginary reaffirms the need to repatriate or digitise and share these records. Nevertheless, a permanent impossible archival imaginary of displaced colonial records will persist.

Radical empathy would also require the repatriation of these records, not only because caregiving from British archivists to Kenyan users would establish a hierarchical caregiving dynamic, but because the relationships of care proposed by Caswell and Cifor would in all cases be better served by local custodianship.

That these new concepts in archival theory sometimes bring us to the same resolutions as legal and rights-based ethical thinking-that repatriation of the Migrated Archives is the only appropriate response to calls for their return, for instance-demonstrates that these concepts will not always be in opposition to the dominant archival paradigm in their effects, even as they cause radical shifts in ways of seeing and doing archival work. In practice, archivists can work through these concepts to discover much more about the records they keep, the processes they enact and the people they assist. As these concepts decolonise archival theory, their implementation decolonises archival practice, and in the case of post-colonial displaced archives, this may literally lead to the decolonisation of collections through repatriation. This depends on the action of individual archivists. Using a critical theoretical approach, in the case of the Migrated Archive, TNA staff would confront power relations that can presently be dismissed as being bound up in geopolitics, government policy, and internal reporting lines, outside of their control. A critical displaced archives theory would enable a recognition that power also operates outside of these structures, in the power to listen to the calls from Kenyan and other archivists, to empathise with the subjects of the records, to advocate for currently excluded users, and critique the formal power structures National Archives staff are operating in and perpetuating. At the same time, archival studies scholars could use the theory to look at other cases, and co-create the theory by listening to and working with archivists, users and records subjects who are subaltern under present systems. This would help to correct the biases in the international dialogues and silences around displaced archives.

Open Access This article is distributed under the terms of the Creative Commons Attribution 4.0 International License (http://creativecommons.org/licenses/by/4.0/), which permits unrestricted use, distribution, and reproduction in any medium, provided you give appropriate credit to the original author(s) and the source, provide a link to the Creative Commons license, and indicate if changes were made. 


\section{References}

Auer L (1998) Disputed archival claims: analysis of an international survey: a RAMP study http://unesd oc.unesco.org/images/0011/001134/113472eo.pdf Accessed 30 Jan 2019

Banton M (2013) "Lost" and "found": the concealment and release of the Foreign and Commonwealth Office "Migrated Archives". Comma: J Int Counc Arch 2012(1):33-46. https://doi. org/10.1080/01576895.2018.1425629

Banton M (2017) Displaced archives in The National Archives of the United Kingdom. In: Lowry J (ed) Displaced archives. Routledge, Abingdon, pp 41-59

Brennan B (2018) Being in the archive: affect and scholarly distance. Arch Manuscri 46(1):3-17. https:// doi.org/10.1080/01576895.2018.1425629

Caswell M (2014) Toward a survivor-centered approach to records documenting human rights abuse: lessons from community archives. Arch Sci 14(3-4):307-322

Caswell M, Cifor M (2016) From human rights to feminist ethics: radical empathy in the archives. Archivaria $81: 23-43$

Caswell M, Gilliland A (2015) False promise and new hope: dead perpetrators, imagined documents, and emergent archival evidence. Int J Hum Rights 19(5):615-627

Caswell M, Punzalan R, Sangwand T (2017) Critical archival studies: an introduction. J Crit Libr Inf Stud 1:2. https://doi.org/10.24242/jclis.v1i2.50

Cifor M (2016) Affecting relations: introducing affect theory to archival discourse. Arch Sci 16(1):7-31

Cifor M, Gilliland A (2016) Affect and the archive, archives and their affects: an introduction to the special issue. Arch Sci 16(1):1-6

Cifor M, Lee JA (2017) Towards an archival critique: opening possibilities for addressing neoliberalism in the archival field. J Crit Libr Inf Stud 1:1. https://doi.org/10.24242/jclis.v1i1.10

Cobain I (2016) The history thieves: secrets, lies and the shaping of a modern nation. Portobello Books, London

Cox D (2017) Revisiting the law and politics of compromise. In: Lowry J (ed) Displaced archives. Routledge, Abingdon

Dahlgreen W (2014) The British empire is "something to be proud of". YouGov, https://yougov.co.uk/ news/2014/07/26/britain-proud-its-empire/. Accessed 27 Mar 2019

ECARBICA (1969) Proceedings of the conference of the Eastern and Central Regional Branch of the International Council on Archives, ECARBICA, Nairobi

Garaba F (2011) Provenance, identification, restitution and management of the liberation struggle heritage in the ESARBICA region. J Soc S Afr Arch 44:26-43

Gilliland A, Caswell M (2016) Records and their imaginaries: imagining the impossible, making possible the imagined. Arch Sci 16(1):53-75

Grimsted PK (2007) Returned from Russia: Nazi plunder of archives in western Europe and recent restitution issues. Institute of Art and Law, Leicester

Harris V (2002) The archival sliver: power, memory, and archives in South Africa. Arch Sci 2:63-86

Kecskeméti C (1977) Archival claims: preliminary study on the principles and criteria to be applied in negotiations. UNESCO, Paris

Ketelaar E (2017) Foreword. In: Lowry J (ed) Displaced archives. Routledge, Abingdon

Koinange M (1958) Letter to District Commissioner of Kabarnet, TNA, FCO 141/6821, African Personalities incl. The Koinanges, f.2090

Lee J (2016) Be/longing in the archival body: Eros and the "endearing", value of material lives. Arch Sci $16: 1$

Leisinger A (1982) Disputed archival claims: a persistent and urgent problem. In: ECARBICA 7, seventh biennial conference and seminar of the east and central Africa regional branch of the international council on archives, Harare, 1982, pp 1-7

Lowry J (2017) Introduction. In: Lowry J (ed) Displaced archives. Routledge, Abingdon

Mnjama N (2007) A chronology of the east and southern African regional branch of the international council on archives resolutions, 1969-2005. ESARBICA J 26:133-180

Mnjama N (2011) Migrated archives revisited. ESARBICA J 30:24-31

Mnjama N (2015) Migrated Archives: the African experience. J S Afr Soc Arch 44:45-54

Mnjama N, Lowry J (2017) A proposal for action on African archives in Europe. In: Lowry J (ed) Displaced archives. Routledge, Abingdon 
Montgomery B (2017) Iraq and Kuwait: the seizure and destruction of historical patrimony. In: Lowry J (ed) Displaced archives. Routledge, Abingdon

Mukula P (1982) Migrated archives and the position of Zambia. In: ECARBICA 7, seventh biennial conference and seminar of the east and central Africa regional branch of the international council on archives, Harare, 1982

Mwaura P (2012) Koinange's death marks the end of a dynasty that reigned in Kiambu, Daily Nation, Kenya, $\quad$ https://www.nation.co.ke/oped/Opinion/-/440808/1499610/-/lmkb7bz/-/index.html. Accessed 10 Sept 2018

Nsibandze N (1996) Southern African archives in exile. SA Arch J 38:84-87

Russell L (2018) Affect in the archive: trauma, grief, delight and texts: some personal reflections. Arch Manuscri 46(2):200-207. https://doi.org/10.1080/01576895.2018.1458324

Stoler AL (2010) Along the archival grain: epistemic anxieties and colonial common sense. Princeton University Press, Princeton

Thiong'o N (1967) A grain of wheat. Heinemann

TNA, (n.d.), Impact, value and affect, http://www.nationalarchives.gov.uk/about/our-research-andacademic-collaboration/our-research-and-people/our-research-priorities/impact-value-and-affect/. Accessed 27 Mar 2019

TNA, CO 822/2935, disposal of files in Tanganyika, 1960-1962

van Beurden J (2017) Treasures in trusted hands: negotiating the future of colonial cultural objects. Sidestone Press, Leiden

Publisher's Note Springer Nature remains neutral with regard to jurisdictional claims in published maps and institutional affiliations.

James Lowry is a Lecturer at the Liverpool University Centre for Archive Studies and Chair of the Association on Commonwealth Archivists and Records Managers. In 2017, Routledge published his edited collection Displaced Archives. 